\title{
DASEIN AND OTHERS: HEIDEGGER'S ONTOLOGY OF INTERSUBJECTIVITY
}

\section{LAWRENCE HASS \\ University of Illinois--Urbana-Champaign}

Martin Heidegger's existential analytic in Being and Time articulates the essential structures and characteristics of Dasein in the endeavor to elucidate the nature of Being in general. As such Heidegger is led to offer an ontology of intersubjectivity, i.e., an account of the essential structures of Dasein's interaction with others. I argue in this essay that Heidegger's depiction of the two intersubjective existentiala--"Being-with" and the "they" with all their attendant modes and features-is an inadequate characterization of the range of interpersonal life. I explicate and explore in the spirit of Heidegger a further existentiale, "Being-questioned", as a required addition to Being and Time. Being-questioned at once challenges Heidegger's position that authenticity is an individual project necessarily occurring in the absence of other people and allows for a richer and thus more plausible ontology of human interaction.

\section{Dasein and Others: Heidegger's Ontology of Intersubjectivity}

What is the metaphysical basis of our relationships with other people? And given that basis, what are the essential structures and
characteristics of these relations? Martin Heidegger seeks to address these questions in Being and Time. My essay 1) situates Heidegger's intersubjective ontology within his larger project of understanding the nature of Being in general, 2) elucidates his interpretation of the two essential structures of intersubjective life and their essential characteristics, and 3 ) recognizes a further and central feature of interpersonality that Heidegger does not articulate--a feature that contributes to a richer understanding of intersubjectivity than Heidegger's account allows.

\section{1}

Heidegger's goal in Being and Time is to "raise anew the question of the meaning of Being" (19), and to "concretely" work out the question as an attempt to come to terms with what Being is. He tells us that "'Being' is the most universal and the emptiest of concepts" and "as such resists every attempt at definition" (21); indeed, everything that is something rather than nothing has Being, but what Being exactly is has been obscured, forgotten, and denigrated through past attempts at understanding it, and through complete neglect of the issue in our everyday lives. In order to 
reformulate this "question about Being" (26), that is, what Being means, what Being is all about, Heidegger chooses as his focus an entity that he believes has the best access to its own being: Dasein, or human being. For Heidegger, Dasein is the one entity (distinct from say, animals and things in the world) that is in the unique position of being able to ask questions about its own Being. In other words, Dasein has--as one of its ways of Beingthe ability to inquire about its own ways of Being and is thus said to have "Being as an issue for itself" (32) in a way all other entities do not. It is in this sense then that Dasein has an ontological priority: Dasein is at once a being which has Being, and is also a being that has the capacity to understand its own Being. And therefore, Heidegger designates Dasein as "the primary entity to be interrogated" (35): Since Dasein's Being provides the best access to Being, i.e., since Dasein can make Being "transparent" to itself, then eludicating Dasein's Being becomes the first and best step toward understanding the nature of Being in general.

Furthermore, Heidegger tells us that if we are to avoid misconceptions about Being in general, we must uncover Dasein's Being by considering the way Dasein is "proximally and for the most part" (37): namely, in its "average everydayness" (38). By considering everyday Dasein, i.e., the way human beings are as they ordinarily go about living their daily lives, Heidegger seeks to elucidate certain "essential structures" that "persist as determinative for the character of [Dasein's] Being" (38), and explore how at least some of those structures obscure the question of Being. In other words, Heidegger's project is to articulate certain essential structures of Dasein's Being and the essential characteristics of those structures that persist in or remain essentially possible for Dasein's Being no matter what particular way of Being Dasein is engaged in at any given moment. These constitutive structures of Dasein's Being are what Heidegger refers to as existentiala and are differentiated from the Aristotelian "categories" precisely because they are essential structures of human beings rather than other entities in the world. Thus, in the First Division of Being and Time Heidegger sets out to develop an "existential analytic", that is, an analysis of the essential structures and the accompanying essential characteristics and modes of Being that constitute the Being of everyday human being. And he does so in the attempt to uncover how and why it is that the Being of everyday Dasein obscures the question of Being and to thereby gain some preliminary insight and access to the question of Being in general.

The first existentiale Heidegger articulates that is relevant to an understanding of his theory of intersubjectivity is referred to as "Being-in" (79). For Heidegger, Dasein's Being, as existing Being, essentially exists in some place; it inhabits a world (80). In other words, since Dasein's Being exists (and that is exactly what it means for Dasein to have Being (681), it must exist someplace, and for Heidegger, the place it exists is in the world. Therefore, the Being of Dasein has Being-in, more specifically, Being-inthe-world as its essential state (80). 
Heidegger further specifies that there are primarily two modes of Being that Dasein manifests in the world as Being-in-the-world: presentat-hand and ready-to-hand. Present-at-hand Being-in-the-world occurs whenever Dasein considers itself and/or other entities in the world as objects in a way that does not recognize Dasein's Being as Being-in-theworld. This is to say, when Dasein treats itself as one entity among others, amidst a field of present, yet isolable objects, Dasein is "forgetting" its fundamental nature as Being-in-the-world. To consider Dasein as one object amidst a collection of other objects is therefore "essentially inappropriate to entities of Dasein's character" (67), for it obscures Dasein's Being as Being-in-the-world and Dasein's unique nature as a Being which can consider its own Being. Nonetheless, Being-present-at-hand is an existential mode of Being-in-the-world, i.e. it is an essentially possible mode for Dasein to be in, a mode that Heidegger believes has come to obfuscate the question of Being he is trying to "raise anew".

The other existential mode of Being-in-the-world is what Heidegger refers to as ready-to-hand. When Dasein exists in this way-"the way in which everyday Dasein always is" (96)--Dasein is not treating itself or other entities as objects in the world, rather Dasein is immersed in a project; Dasein is acting in a way that utilizes other entities as equipment requred for the project, rather than thinking of them as entities which are isolable from the world. And since ready-to-hand Being-in-the-world does not obscure Dasein's nature as Being-in-the-world (as present-at-hand objectification does), Heidegger holds that ready-to-hand Being-in-theworld is more primary than present-at-hand Being-in-the-world (96), that is, "truer" to Dasein's nature. Heidegger refers to this primary mode of Being-in-the-World as concern: Dasein, as essentially Being-in-the-World, concerns itself first and foremost with projects, with interacting with equipment as means to accomplish certain tasks; Present-at-hand Being-inthe-world is an essentially possible break from these projects in a way that obscures Dasein's Being.

\section{II}

The above exposition provides the necessary background for characterizing Heidegger's theory of intersubjectivity. Having argued that Dasein's Being is fundamentally a Being-in-the-world that primarily takes up one of two different modes of Being-in-the-world, Heidegger, as the next step of his existential analytic, asks the question "who it is that Dasein is in its everydayness" (149). Heidegger maintains that answering this question through an analysis of everyday Dasein will delineate two further essential structures, i.e., existentiala, of Dasein's Being: "Beingwith" and the "they". These existentiala, as answers to the question of the "who" of Dasein, constitute Heidegger's theory of intersubjectivity since, for Heidegger, the "who" of Dasein as Being-in-the-world is not some isolable, present-at-hand subject cut off and separable from the world and others in 
the world, but rather consists precisely of our relationships with others. Hence, this section of my essay elucidates these two existentiala and the essential characteristics of human relationships that follow from them.

To begin an articulation of the existentiale "Being-with", we recall that for Heidegger Dasein's Being as existing (which it is by definition) is thereby essentially Being-in-the-world. Thus, ready-to-hand Being-inthe-world which does not obscure Dasein's Being as Being-in-the-world is a more primary, i.e., a mode more true to Dasein's Being, than present-athand Being-in-the-world; present-at-hand Being-in-the-world is always possible, yet both is derived from and distorts ready-to-hand Being-in-theworld. Now, for Heidegger, when everyday Dasein is concerned with projects, immersed in a world of concern as a "workshop" within which tasks are performed, Dasein necessarily "encounters" others in one form or another. Others are either directly a part of Dasein's environment-perhaps a feature of a project such as the person who sells Dasein a book (153)--or they are alluded to in the equipment we use or the part of the "workshop" we are concerned with-such as the persons who wrote the book and who own the bookshop (153-54). Importantly, in ready-to-hand Beingwith the other is not encountered as just one piece of equipment among many, nor as an isolable object in the world; the other is experienced as another Dasein. Indeed, Heidegger tells us: "these entities [i.e., othersl are neither present-at-hand nor ready-to-hand; on the contrary they are like the very Dasein which encounters them, in that they are there too, and they are with it " (154). This is the sense then in which everyday Dasein has as one of its essential structures "Being-with" and the resulting essential characteristic "Dasein-with". As ready-to-hand Being-in-the-world Dasein is necessarily with other Dasein; they are either among our projects immersed in their own projects, or their fundamental nature as ready-tohand Being-in-the-world is alluded to in the "equipment" of Dasein's projects. To reiterate then, for Heidegger, "the world of Dasein is a wilhworld. . . Being-in is Being-with others. Their Being-in-themselves within-the-world Igiven in Dasein as Being-withl is Dasein-with" (155). For one to be puzzled by the question of whether or not there are other "subjectivities", other "selves" accompanying human bodies we observe in the world (as some philosophers have been) is to treat Dasein as presentat-hand, that is, as an "object" that inheres within bodies; it is to neglect that Dasein primarily just is its ready-to-hand Being-in-the-world and is thus to obscure Dasein's Being as essentially Being-with.'

'While Heidegger's exposition does offer an explanation to the traditional problem of the other by maintaining Dasein's Being just is its Being-in-theworld and not a Present-at-hand subject within a body, I think there is a question that still remains: How is it that Dasein can ever fully experience the Being-in-the-world of other Dasein? Or to put it another way: Can Dascin only experience other human beings' Being-in-the-world only 
"Being-with" as an essential structure of Dasein's Being as Being-inthe-world is what Heidegger refers to as solicitude. "Solicitude" as "a term for an existentiale" (158), i.e., the existentiale Being-with, is differentiated from "concern" because the entities encountered in solicitude are other Dasein, not ready-to-hand equipment. Heidegger further fills out the nature of Being-with as solicitude by briefly articulating different modes of solicitude which fall into two categories: The "Indifferent" and the "positive" (158). Some examples of Indifferent modes of Being-with are "passing one another by, not 'mattering' to another" (158); Heidegger refers to them as "deficient", and emphasizes that everyday Dasein "maintains itself proximally and for the most part in the deficient modes of solicitude" (158). In short, Heidegger is telling us that although we fundamentally share a world with other people, we are for the most part indifferent to them as we go about the business of our daily lives: We walk past them, we drive by them, we talk past them and ignore them in our everyday concern with projects.

For all that however, Heidegger suggests two "positive" modes of solicitude: 1) "leaping-in" and 2) "leaping-ahead" (158-159). Heidegger's reference to these modes as "positive" does not connote a positive value to them, that is, as somehow "better" than the Indifferent modes, rather "positive" denotes ways Dasein actively behaves toward other Dasein. When Dasein "leaps-in" for another Dasein, Dasein "takes over for the Other that which with (the otherl is to concern himself" (158). Leaping-in takes over the other's project and thereby throws the other out of it (158). It is a mode of Being-with in which one Dasein "dominates" the other and results in the latters' dependency on the former. This mode would occur when say, one student writes a paper for another student, or when one person does all the talking for another in a social situation. The other positive mode of Being-with that Heidegger details is "leaping-ahead". For one to leap-ahead of another is to carry out a project which allows the other to see that project as a possible concern of theirs--say when parents' talking among themselves serves as a model to a child who is learning to speak. In leaping-ahead, one Dasein's concern "helps the other become transparent to himself. ... and free for [the project]" (159). Heidegger concludes these passages by telling us that "Everyday Being-with-one-another maintains itself between the two extremes of positive solicitude" (159). For Heidegger then, these two types of modes--the Indifferent and the positive--more fully characterize the existentiale Being-with as a fundamental structure of Dasein's Being-in-the-world.

insofar as they intersect Dasein's Being-in-the-world? It seems that a troubling solipsism may result from Heidegger's position here. As interesting as this whole issue is the focus and intent of my paper prevent further exploration of this issue. 
The other existentiale of Dascin's Being that Heidegger develops in Being and Time is what he refers to as the "they". He begins exposition of the "they" by recalling that it is in our ready-to-hand Being-in-the-world, i.e., our concern with projects in the environment, that "the Others are encountered as what they are; they are what they do" (163). Indeed, in this primary mode of Being, others are not present-at-hand selves hidden within bodies, rather they are there as Dasein, with Dasein. Heidegger tells us that as a result of this fundamental Being-with of Dasein's Being, Dasein has "constant care as to the way one differs from them"--whether one is like them, inferior to them, or superior to them (163-64). And this "constant care" with how we compare with other Dasein continually "disturbs" Being-with, even though it may go unnoticed by Dasein. Heidegger refers to this disturbance of Dasein which is an essential characteristic of Being-with, as everyday Dasein's distantiality. This distantiality of Being-with means that Dasein "itself is not; its Being has been taken away by the Others" (164). In other words, Heidegger is telling us that everyday Dasein as fundamentally Being-with others entails that Dasein's Being is constituted by distances to and from others that are beyond its control; Dasein is subjected to others (164). Further, Heidegger tells us that this subjugation of Dasein to others is amorphous, anonymous, and constant: We cannot characterize it by saying this, that, or even all person are to blame. The "they" that Dasein is essentially subjected to is a non-distinguishable, yet ever present feature of our daily lives (164); it is the 'who' of everyday Dasein (164). Some examples Heidegger offers of the "they" are when one takes public transportation or reads the paper: Here "Being-with-one-another dissolves one's own Dasein completely into the kind of Being of 'the Others' in such a way. . .that the Others. . .vanish more and more" (164). Thus, the Being of Everyday Dasein is "dictated to" by the elusive "they" without even realizing it. To be sure, for Heidegger "the 'they', which is nothing definite and which all are...prescribes the kind of Being of everydayness" (164).

Moreover, Heidegger tells us that because everyday Dasein is dispersed into and lost among the "they" it becomes a "they-self" (167), i.e., it is inauthentic Dasein. Inauthentic Dasein, for Heidegger, fist is everyday Dasein precisely because it has the "they" as an essential structure of its Being. The "they" makes Dasein's Being inauthentic because the "they" and Dasein's "they-self" obscures Dasein's nature as Being-inthe-world, and importantly obscures that Dasein as Being-in-the-world fundamentally is the projects and concerns it takes up for itself. Insofar as authentic Dasein is possible, i.e., Dasein that comes to recognize its own nature as Being-in-the-world and can thereby take up possible ways of Being-in-the-world on its own terms apart from the "they" (167-68), it is only possible as a modificalion of Dascin's being lost among the "they" as it essentially is (168). This then is why Heidegger holds that Dasein is essentially characterized as falling: Dasein as Being-with, as a "they- 
self", has "fallen away from itself, and has fallen into the 'world"' (220). Heidegger further specifies that when everyday Dasein "falls" into the "averageness" of the "they" it also takes up inauthentic modes of Being-inthe-world which are guided by the "they": ambiguity, idle talk, and curiosity (210-11). These modes of Being-in-the-world which are reinforced by the "they" are essential characteristics of everyday Dasein; each of them in their own way prevent Dasein from authentically choosing a project, and insures that Dasein is "constantly going wrong in its projects as regards the genuine possibilities of Being" (218).

Section II of this essay has elucidated Heidegger's two existentiala of everyday Dasein which are central to his theory of intersubjectivity, i.e., Being-with and the "they", and has iterated certain essential characteristics or modes of each of these structures. Dasein, in Heidegger's view, is fundamentally Being-with others as a result of its primary nature as ready-to-hand Being-in-the-world. However, as Being-with, Dasein is also essentially inauthentic: it "falls" into and is swept away in the "publicness" of the world in which it lives; it gets subjugated and lost amidst the averageness and anonimity of the "they" and therefore cannot recognize its own potentiality as Being-in-the-world for taking up its own way of Being-in-the-world, that is to say, its own authentic existence. Such authenticity can only be achieved against the backdrop and ever-pressing flow of the "they"; it is always tenuous and conditioned by the "they", and is thus rarely achieved by Dasein. Indeed, in Heidegger's view, the nature of intersubjectivity is such that while other Dasein are an ever-present feature of Dasein's Being, they also hinder Dasein's understanding of its own Being, and thereby prevent Dasein from being fully aligned with its own Being.

III

In this Concluding Section I raise and explore an objection to Heidegger's ontology of intersubjectivity: namely, that his account fails to provide a thorough characterization of the way Dasein interacts with other Dasein; more specifically, the way in which another's interests, concerns, or behavior often make us question and sometimes alter our own interests, concerns, or behavior. This is all to argue that while Heidegger attempts to analyze the essential structures and accompanying characteristics of everyday Dasein, he does not recognize at least one other central feature of intersubjectivity: namely, the way in which we often develop our own responses to other peoples' ideas, projects, and/or behavior; more precisely, the way in which other peoples' way of being present perspectives to us that effectively question us, that require us to develop our own way of being toward that perspective. In the spirit of Heidegger, this is what $\mathbf{I}$ refer to as "Being-questioned". Indeed, as we live our lives and interact with some of the people around us, with us, we are regularly in the position of Being-questioned by them, of being presented with perspectives 
of other people that require us to attach meaning to them or that inspire us to respond to them. This questioning need not be literal question-asking by another (though sometimes it clearly is so); it might be what occurs when a colleague expresses his/her dogmatic belief in a political theory, or when we see someone wearing something we like, or someone behaving unusually. To reiterate, Being-questioned occurs whenever we are confronted or provided with another point-of-view/perspective different from our own which strikes us as a way of Being-in-the-world that we are not, but that we need to make something of. Being-questioned need not be something we are consciously aware of, i.e., it is not just a present-at-hand objectification of another person; on the contrary, it also occurs in ready-to-hand Being-inthe-world, in and among our everyday concern with our projects as they intersect with other people's projects. Here, we see how another person is in-the-world and respond in some way to it as our own way of Being-in-theworld without being objectively aware of it, as when say, an apprentice develops her own style in response to the master's technique, or when a student criticizes a position articulated by his teacher. Indeed, Beingquestioned appears to happen regularly for Dasein: We are questioned by others, their Being-in-the-world, their projects and the remnants of their projects; it appears to be how we learn some things, how we come to acquire new projects or new twists on old projects, how we come to develop original ideas out of old positions, how we often interact with the books we read, how we are inspired to criticize positions or ideas that we encounter.

It might seem as if what 1 have described as Being-questioned is roughly the same as the "positive" mode of solicitude that Heidegger calls "leaping-ahead". However, I maintain that Being-questioned goes beyond "leaping-ahead" for the following reasons. First of all, and most importantly, I think that Being-questioned is not just an essential mode of solicitude, but is actually an essential structure of Dasein, i.e., an existentiale. It is not that Being-questioned is merely a secondary function of Being-with other Dasein, rather, Being-questioned is an essential part of what it means to be a human being in the world. We recall that Heidegger tells us that Dasein's Being just is Being-in-the-world, for that is what it means for Dasein to have Being. But what Heidegger does not seem to recognize here (as say, Merleau-Ponty does so well) is that Being-in-theworld is always Being-in-the-world at a certain location, from a certain perspective that necessarily occludes other perspectives, e.g., I perceive only the bindings of books on my shelves, or the front of my computer while engaged in the project of writing. In other words, I would insist that to Bein-the-world is to really be in the world, to be among the world, to experience parts or aspects of the world which sometimes allude to other, perhaps hidden aspects of the world--say, when I read the first page of a novel. This then is the sense in which I maintain that Dasein as Being-inthe-world just is Being-questioned: Whether engaged in projects or presentat-hand objectification, human beings live in a world of perspectives that 
at least sometimes draws us in and questions us. However, it is when we are with other people, presented with other ways of Being-in-the-world through their behavior or their ideas, that we are particularly questioned about our own Being-in-the-world, and this is why Being-questioned finds emphatic manifestation in our relations with other people. But it is not just that Being-questioned is an essential characteristic or mode of Being-with, rather, in my view, Being-questioned is the very nature of Dasein's Being as Being-in-the-world that finds particular emphasis in our relationships with others.

A second reason I do not think "leaping-ahead" and Being-questioned are equivalent is that, in Heidegger's terms, to "leap-ahead" is to leapahead of another's potentiality-for-being in a way that allows another to see that Being-in-the-world as a potentiality for it (158-59). In Heidegger's very brief description of this mode of solicitude, "leapingahead" seems to denote some sort of modeling relation between one Dasein and another. In my view, Being-questioned by another is not a modeling relationship; Being-questioned is not just taking over another's Being-inthe-world; it is being presented with a perspective toward the world that allows one to manifest a wholly new way of Being-in-the-world. It is not just that the other's Being-in-the-world impresses itself upon one, rather the other's perspective in a sense, confronts one, and requires Dasein to make its own perspectival response to it. For example, Being-questioned by one's politically dogmatic colleague does not mean that one also takes up the dogma, but rather that one develops a new way of Being-in-the-world in response to the dogma, say, a more critical eye toward what the friend might say in the future, or a more critical approach to political claims altogether. Indeed, I think that if Heidegger means "leaping-ahead" to be Dasein's Being-in-the-world serving as a model to another Dasein, then Being-questioned is a different phenomenon than "leaping-ahead". For Being-questioned captures how our interactions with other people's perspectives bring about a way of Being-in-the-world different from the perspective that inspired it, not just a model of that perspective.

Furthermore, given Being-questioned as an additional existentiale of Dasein that finds particular manifestation in the interaction between Dasein, and also given Heidegger's description of authentic Dasein as Dasein that comes to recognize its own nature as Being-in-the-world that can take up possible ways of Being on its own terms apart from the "they" (167), then we see that Being-questioned by others is one way in which Dasein can become authentic. For Being-questioned by another's ideas, behavior, or projects is not just the taking over of another's way of Being-inthe-world, rather it is being presented with or confronted by a perspective of another's Being-in-the-world that requires us to develop a response to it. And it is in the endeavor to develop a response to Being-questioned by others that Dasein is authentic in Heidegger's sense: To develop a response to another's ideas, projects, or behavior is for Dasein to come to terms with 
its own possible responses to the other; it is for Dasein to take up a new way of Being-in-the-world that is perceived as possible through the other's question.

Recognition of this interactive authenticity, i.e., a form of authenticity made possible expressly through our intersubjective relationships, points to a distinct weakness in Heidegger's general position, for he seems to hold that authenticity is achieved only through individualization, through separating oneslef off from others. We are told that anxiety is what makes Dasein "free" for its own potentiality-for-Being (232), and that this potentiality-for-Being is in each case mine (276). Given the existentiale of Being-questioned it is not just individualization resulting from anxiety one feels about Nothingness that makes Dasein recognize its own potentialityfor-being, i.e., its own authenticity, rather other Daseins' Being-in-theworld allows us to find our own possible ways of Being in response to their ways of Being. I am suggesting here that authenticity is a more interactive process than Heidegger is able to see; Heidegger's picture of authenticity as a purely individual process that occurs fully apart from other people is simply too myopic given the kinds of interaction and interpersonal exchanges we often have with others. In short, Heidegger holds that authenticity must take place "detached" from the "they" (168), and thereby concludes that authenticity is an individual project. The flaw here is for Heidegger not to recognize that there is a least one phenomenon of human interaction--Being-questioned--that, while perhaps occurring against the backdrop of the "they", is initiated by other Dasein and yet seems to require Dasein to find its own response. Being-questioned recognizes that Dasein's Being-in-the-world is often a product of what it makes of another Dasein's Being-in-the-world.

At this point I would like to reiterate my lines of disagreement with Heidegger's intersubjective ontology in simpler terms. First of all, I agree with Heidegger that human beings are constantly with other human beings; as we move through our days we encounter others as they are alluded to in the world or else experience others as a direct part of that world. I also agree that there is a "they" of sorts which we can get caught up in as we live our lives--say, when we become too concerned with the things other people say and do. But I disagree with Heidegger that these two positions and their accompanying claims captures the full range of human interactions; in fact, 1 think the people we talk with, work with, learn from, are friends with, are in love with, often present to us new and challenging perspectives different from our own--whether in our conversations, our mutual projects, our reading of their ideas, or the experiencing of their projects. And these perspectives, these alternate ways of thinking, speaking, writing, acting, etc. contribute to our being able to come up with our own way of thinking or acting in response to them. This then is the sense in which 1 hold that as human beings we are "questioned" by others: Sometimes in the experience of another person we are confronted 
with a position or a behavior that allows us to think about things in a way we could not have without them, or we have to attach significance to their actions in order to make sense of them. It is not that we are always questioned by others, nor is it that we are always able to find a response to or meaning in the other's questions--often we just pass others by or else simply do not notice or do not have a response to their "questions". But at times in the course of our daily interactions we do find ourselves in a position of having to develop a response to the perspectives they present us. And furthermore, 1 hold that this kind of questioning by the other is not just presenting a model that we take up for ourselves, rather it requires us to create our own ways of being in response: When my colleague says that the Congress is dominated by the political Right I do not simply accept that way of thinking for myself, rather I question it, I think about it, perhaps I even reject it; I wrestle with the issue on my own terms to make sense of it. Certainly it is not the case that one can always make such an "original" response to the questions of the other, but that sometimes we do is enough to demonstrate that there is at least one aspect of intersubjective relationships--an aspect that seems to challenge Heidegger's account of authentic Dasein-that he does not articulate in Being and Time. ${ }^{2}$

In conclusion then, although Heidegger articulates two essential structures of Dasein's Being that account for there being other people in the world and the ways in which other people obscure Dasein's Being as Beingin-the-world, he fails to recognize that our interactions with others sometimes question us, throw us back on our own Being-in-the-world. The additional existentiale which I have referred to as "Being-questioned" seems pervasive throughout interpersonal relationships, and indicates that authentic Being need not be a solitary project which takes place against the ever-pressing flow of other people. Thus it is that Heidegger provides a misleading and incomplete account of human relations and a troubled

${ }^{2}$ What is interesting to note here is that without some kind of interactive picture of our relationships with others it does not seem as if Heidegger could even claim that a reader of Being and Time itself had Being authentically. In other words, under Heidegger's picture it appears as if reading Being and Time is inauthentic Being; trying to come to terms with the words and ambiguities in the work would seem to prevent one from understanding our own nature as Being-in-the-world even though that is what the book is about! In short, without a modification of his position to include as an existentiale something like Being-questioned, Heidegger has provided us with no understanding of how the reader can be questioned, altered or related to Heidegger's own writing on the subject. It is not that it would just have been more helpful and even accurate for Heidegger to have amplified his depiction of intersubjectivity; it becomes central to the plausibility of his work that he can account for the type of relationship a reader has to his position. 
depiction of authentic Being: Neither of these characterizations capture the fully interactive nature of human Being--a nature that must be recognized by any adequate ontology of intersubjectivity. 
Works Cited

Heidegger, Martin. Being and Time. 1st English Edition from the 7th German Edition. Trans. by John Macquarrie and Edward Robinson. Oxford: Basil Blackwell, 1962. 